\title{
PENGARUH KEPEMIMPINAN, MOTIVASI DAN KOMITMEN ORGANISASI TERHADAP KEPUASAN KERJA DAN KINERJA PEGAWAI NEGERI SIPIL UNIVERSITAS RIAU PEKANBARU
}

\author{
Nyoto $\left.{ }^{*}\right)$, Erpan Rajab ${ }^{2}$ \\ ${ }^{1}$ Institut Bisnis dan Teknologi Pelita Indonesia, Pekanbaru, Indonesia \\ nyoto@lecturer.pelitaindonesia.ac.id \\ ${ }^{2}$ Institut Bisnis dan Teknologi Pelita Indonesia, Pekanbaru, Indonesia \\ erpanrajab.febunri@gmail.com
}

\begin{abstract}
ABSTRAK
Penelitian ini bertujuan untuk mengetahui dan menganalisis pengaruh kepemimpinan, motivasi dan komitmen organisasi terhadap kepuasan pega wai. Untuk mengetahuidan menganalisis pengaruh kepemimpinan, motivasi da $\mathrm{n}$ komitmen terhadap kinerja pegawai. Pengaruh kepuasan terhadap kinerja pegawai. Pengaruh kepemimpinan, motivasi dan komitmen organisasi terhadap Kinerja melalui kepuasan kerja pada Universitas Riau Pekanbaru. Populasi yang penulis jadikan objek penelitian ini adalah Pegawai Negeri Sipil pada Universitas Riau tahun 2015 sebanyak 170 Orang. Sa mpel dalam penelitian ini sebanyak 170 orang. Data yang digunakan dala m penelitian ini adalah data primer dan data sekunder, sedanglan teknik pengumpulan data menggunakan kuisioner. Teknik analisis data y a ng digunakan dalam penelitian ini adalah path analisis, dengan menggunakan software SPSS. Hasil penelitian ini menunjukkan kepemimpinan, Motivasi dan Komitmen organisasi berpengaruh positif dan signifikan terhadap kepuasan kerja. Kepemimpinan, Motivasi, Komitmen organisasi berpengaruh positif dan signifikan terhadap kinera pegawai. Kepuasan kerja pegawai berpengaruh positif dan signifikan terhadap kinerja pegawai. Kepemimpinan berpengaruh terhadap kinerja melalui kepuasan kerja di Universitas Riau. Motivasi berpengaruh terhadap kinerja melalui kepuasan kerja di Universitas Riau. Komitmen organisasi berpengaruh terhadap kinerja melalui kepuasan kerja di Universitas Riau.
\end{abstract}

Kata Kunci: Kepemimpinan, Motivasi dan Komitmen Organisasi Terhadap Kepuasan Kerja dan Kinerja Pega wai.

\section{ABSTRACT}

This study aims to determine and analyze the effect of leadership, motivation and organizational commitment on employee satisfaction. To find out and analyze the effects of leadership, motivation and commitment on employee performance. Influence of satisfaction on employee performance. The influence of leadership, motivation and organizational commitment to performance through job satisfaction at Riau Riau University. The population that the authors make the object of this study is the Civil Servants at the University of Riau in 2015 as many as 170 people. The sample in this study were 170 people. The data used in this study are primary and secondary data, while data collection techniques are using questionnaires. The data analysis technique used in this study is path analysis, using SPSS software. The results of this study indicate that leadership, motivation and organizational commitment have a positive and significant effect on job satisfaction. Leadership, Motivation, Organizational commitment has a positive and significant effect on employee performance. Employee job satisfaction has a positive and significant effect on employee performance. Leadership influences performance through job satisfaction at Riau University. Motivation affects performance through job satisfaction at the University of Riau. Organizational commitment influences performance through job satisfaction at Riau University.

Keywords: Leadership,Motivation and Organizational Commitment to Job Satisfaction and Employee Performance . 


\section{PENDAHULUAN}

Upaya menunjang kelancaran penyelenggaraan pemerintah dan pelaksanaan pembangunan nasional terutama kualitas aparatur Negara pada pokoknya tergantung dari kualitas pegawai negeri sebagai pelayan masyarakat. Kedudukan dan peranan Pegawai Negeri Sipil adalah penting, karena Pegawai Negeri Sipil adalah unsur aparatur Negara, untuk menyelenggarakan pemerintahan dan pembangunan dalam rangka usaha mencapai tujuan nasional. Tujuan itu dapat dicapai dengan adany a pegawai negeri sipil yang penuh kesetiaan akan ketaatan kepada Pancasila, Undang-Undang Dasar 1945 Negara dan Pemerintahan serta yang bersatu padu, bermental baik, berwibawa, kuat, berdaya guna, berhasil guna, bersih, berkualitas tinggi dan sadar atau tanggung jawabnya sebagai unsur aparatur Negara. Abdi Negara yang mempunyai kewajiban menyelenggarakan pelayanan secara adil d an merata kepada seluruh unsur elemen masyarakat di Negara ini tanpa ada perbedaan (Pasal 3 UU 43 Tahun 1999). Kondisi birokrasi di Indonesia menunjukkan bahwa citra perilaku individu dalam organisasi pemerintahan Indonesia tidak cukup baik. Citra yang disandang pegawai pemerintah di Indonesia yang disebut Pegawai Negeri Sipil (PNS) tampak telah tertanam pada masyarakat luas, kesan malas, tidak disiplin, tidak produktif, datang hanya mengisi daftar hadir, pelayanan tidak memuaskan, bahkan cenderung untuk minta dilayani serta bekerja berdasarkan perintahdan bukan menunjukkan inovasi dan kreatifitas (Putra, 2014)

Universitas Riau merupakan instansi Pemerintah yang dibentuk berdasarkan keinginan d an citacita bersama antara masyarakat dan pemerintah daerah Riau. Keinginan ini diwujudkan dengan membentuk Panitia Persiapan Perguruan Tinggu Riau (P3TR) di Tanjung Pinang. Namun, setelah ibukota propinsi Riau pindah ke Pekanbaru, maka Panitia ini dipindahkan ke k ota ini. Pelopor dari pendirian perguruan tinggi tersebut ialah Kolonel Kaharuddin Nasution, Datuk Wan Abdurrahman, Soes man Hs. dan Drs. Sutan Balia. Usaha keras kepanitian itu dibentuklah Yayasan Universitas Riau, setelah itu didirikan perguruan tinggi. Perguruan tinggi ini diberi nama dengan Universitas Riau dengan Surat Keputusan Yayasan Universitas Riau No.02/KPTS/JUR/62 Tanggal 25 September 1962, selanjutnya diperkuat dengan Surat Keputusan Menteri Perguruan Tinggi dan Ilmu Pengetahuan No.123 tanggal 20 September 1963 yang berlaku sejak 1 Oktober 1962 Satu tahun berikutnya dibuka pula Fakultas Ekonomi dan Fakultas Ilmu Pasti dan Ilmu Alam. Kemudian pada tahun 1964 didirikan: Fakultas Perikanan, sehingga lengkaplah Universitas Riau sebagai sebuah universitas dengan dua fakultas eksakta dan tiga non-eksakta. Dalam melaksanakan tugas tersebut, Kementerian Riset dan Tekhnologi dan Pen didikan Tinggi (RISTEK DIKTI) di tuntut untuk memiliki sumber daya manu sia y ang mempunyai ko mitmen kerja yang tinggi agar visi, misi dan nilai-nilai Universitas Riau bisa di capai se suai y ang di harapkan. Pegawai diharapkan dapat mewujudkan visi Universitas Riau "Menjadi Universitas Riset, Unggul,Bermartabat dibidang Sains dan Tekhnologi Di Kawasan Asia Tenggara Tahun 2035" Artinya, jika pegawai bisa melaksanakan tugas dengan penuh tanggung jawab, in teraktif dan terpercaya maka sektor pendidikan yang baik akan bisa tercapai.

Pegawai yang terampil dan handal sangat dibutuhkan dalam mengaplikasikan selu ruh ke giatan manajemen pada saat ini. Kinerja pegawai perlu diperhatikan serta ditingkatkan dengan baik untuk mendukung tujuan visi dan misi yang telah ditetapkan dalam sebuah organisasi. Kinerja merupakan hasil pekerjaan yang mampu dicapai secara kualitas dan kuantitas dengan penuh tanggung jaw ab yang telah ditetapkan dan disepakati bersama di dalam suatu organisasi. Kinerja juga harus mampu memperhatikan 
periode waktu untuk melaksanakan dan mencapai target yang diinginkan dalam suatu organisasi. Kinerja yang lebih tinggi mengandung arti terjadinya peningkatan efisiensi, efektivitas, atau kualitas y ang lebih tinggi dari penyelesaian serangkaian tugas yang dibebankan kepada seorang pegawai dalam suatu organisasi. Sumbangan yang terbesar bagi organisasi demi tercapainya kinerja organis asi y ang optimal serta fungsi-fungsi organisasi dapat dilihat berdasarkan kinerja pegawai. Kinerja organis asi tid ak lep as dari peran pegawai nya, semakin baik kinerja pegawai maka kinerja organisasi akan meningkat. Menilai kinerja pegawai Universitas Riau berdasarkan kualitas, target, waktu dan taat asas. Berdasarkan indikator penilaian tersebut, maka diperoleh nilai kinerja pegawai Universitas Riau dapat dilihat pada Tabel1 sebagai berikut:

Tabel 1. Kinerja Pegawai di Universitas Riau Tahun 2014-2018

\begin{tabular}{|c|l|c|c|c|c|c|}
\hline No & \multicolumn{1}{|c|}{ Kategori } & $\mathbf{2 0 1 4}$ & $\mathbf{2 0 1 5}$ & $\mathbf{2 0 1 6}$ & $\mathbf{2 0 1 7}$ & $\mathbf{2 0 1 8}$ \\
\hline 1 & Amat Baik (91-100) & 10 & 11 & 9 & 7 & 5 \\
\hline 2 & Baik (76-90) & 117 & 125 & 135 & 132 & 128 \\
\hline 3 & Cukup Baik $(61-75)$ & 21 & 23 & 25 & 27 & 37 \\
\hline 4 & Sedang $(51-60)$ & - & - & - & - & - \\
\hline 5 & Kurang $(<60)$ & - & - & - & - & - \\
\hline \multicolumn{2}{r}{ Jumlah } & $\mathbf{1 4 8}$ & $\mathbf{1 5 9}$ & $\mathbf{1 6 9}$ & $\mathbf{1 6 6}$ & $\mathbf{1 7 0}$ \\
\hline
\end{tabular}

Sumber: Universitas Riau, 2020

Berdasarkan pada Tabel 1 di atas, dapat dilihat bahwa jumlah pegawai di Universitas Riau dalam kurun waktu lima tahun dengan jumlah yang berbeda, dan cenderung mengalami peningkatan. Akan tetapi peningkatan jumlah pegawai tidak diikuti peningkatan kinerjanya, dimana da pat dilihat pegawai yang memiliki kinerja amat baik dan baik dari tahun ketahun selalu mengalami penuru nan, sebaliknya pegawai yang mendapatkan nilai cukup baik dan sedang cenderung mengalami peningkatan, dengan kata lain pegawai yang mempunyai kinerja baik semakin menurun sehingga ini akan men yebabkan kinerja organisasi juga mengalami penurunan. Menurut Kasmir (2016) faktor-faktor yang mempengaruhi kinerja diantarnya adalah Kepemimpinan, motivasi, komitmen organisasi dan kepuasan kerja. Kemudian Robbins dan Judge (2008) faktor-faktor yang mempengaruhi kinerja diantaranya adalah motivasi, kepemimpin an . Edison, Anwar dan Komariyah (2018) faktor-faktor yang mempengaruhi kinerja adalah motivasi, kepemimpinan dan komitmen.

Faktor pertama yang dapat mempengaruhi kinerja seseorang pegawai negeri sipil adalah faktor kepuasan kerja. Kepuasan kerja sangat penting di dalam suatu organisasi dan perusahaan, karena perusahaan sebagai suatu sistem sosial yang mempekerjakan manusia. Pegawai yang mengalami kepuasan kerja diharapkan dapat meningkatkan kinerja. Kepuasan kerja merupakan salah satu unsur yang ada pada setiap bidang pekerjaan. Tanpa ada kepuasan kerja seseorang tidak akan bekerja seperti y ang diharapkan, sehingga tujuan organisasi tidak tercapai. Kreitner \& Kinicki (2015), bahwa kepuasan kerja sebagai efektivitas atau respons emosional terhadap berbagai aspek pekerjaan. Definisi ini mengandung pengertian bahwa kepuasan kerja bukanlah suatu konsep tunggal, sebaliknya seseorang dapat relatif puas dengan suatu aspek dari pekerjaannya dan tidak puas dengan salah satu atau beberapa aspek lain nya. 
Fenomena yang terjadi di Universitas Riau, mengenai Kepuasan Kerja Pegawai Negeri Sipil berdasark an laporan data pelanggaran aturan 3 tahun terakhir dan melakukan wawancara diantaranya:

1. Pembayaran Remunerasi yang belum berjalan sebagaimana mestinya

2. Belum ada perbedaan tingkatan pada bagian Kepala Sub Bagian kebawah, padahal kalau ditinjau dari tugas dan tanggung jawab berbeda

3. Belum dibayarkanya Remunerasi seperti ini karena belum adanya acuan Penilaian Kinerja dilingkungan Universitas Riau, tentunya unsur dari pendapatan pegawai negeri sipil inilah yang menyebabkan kepuasan kerjanya semakin menurun.

4. Promosi jabatan yang tidak jelas juga merupakan sumber ketidakpuasan pekerjaan.

5. Tidak adanya penghargaan atas pengalaman dan keahlian serta promosi yang tidak dirancang dengan benar dapat menimbulkan sikap apatis dalam bekerja serta tidak memberikan harapan yang lebih baik dimasa depan.

6. Isi pekerjaan itu sendiri, misalnya seseorang yang tidak menyukai berhadapan dengan orang banyak justru diberikan jabatan pada hubungan masyarakat, orang yang tidak suka dengan pekerjaan yang berhubungan dengan angka ditempatkan pada bagian anggaran atau dengan input orang lain.

\section{METODE}

Lokus penelitian ini dilaksanakan di Universitas Riau, yang beralamat di Kampus Bina Widya Km.12.5 Simpang Baru Pekanbaru 28293. Waktu penelitian bulan Januari 2020 sampai dengan Maret 2020. Populasi adalah keseluruhan dari objek atau individu yang memiliki karakteristik (sifatsifat) tertentu yang akan diteliti (Silaen et al, 2013). Populasi yang penulis jadikan objek penelitian ini adalah Pegawai Negeri Sipil pada Universitas Riau tahun 2015 sebanyak 170 Orang. Sedangkan sampel adalah sebagian dari populasi yang diambil dengan cara-cara tertentu untuk diukur atau diamati karakteristiknya, kemudian ditarik kesimpulan mengenai karakteristik tersebut y ang dianggap mewakili populasi (Silaen et al, 2013). Adapun cara penentuan jumlah sampel dengan menggunakan sensus sampling. Artinya sampel yang diambil adalah 170 orang/ responden. Adapun pengklasifikasian populasi dan sampel tersebut adalah sebagai berikut :

Tabel 2. Populasi dan Sampel

\begin{tabular}{|c|c|c|c|}
\hline No. & Keterangan & Populasi & Sampel \\
\hline 1 & PNS Rektorat & 45 & 38 \\
\hline 2 & PNS Fak.Ekonomi & 30 & 20 \\
\hline 3 & PNS Fak.Fisipol & 25 & 19 \\
\hline 4 & PNS Fak.Keguruan & 25 & 15 \\
\hline 5 & PNS Fak. Perikanan & 25 & 12 \\
\hline 6 & PNS Fak. Pertanian & 20 & 15 \\
\hline & Jumlah & $\mathbf{1 7 0}$ & $\mathbf{1 7 0}$ \\
\hline
\end{tabular}

Sumber : Data Olahan. 
Kebijakan: Jurnal Ilmu Administrasi

Volume 13, Nomor 1, Januari 2022

E-ISSN: 2656-2820

P-ISSN 1829-5762

Pengolahan data hasil penelitian pada tahap awal dilakukan dengan metode deskriptif. Analisis deskriptif adalah statistik yang digunakan untuk menganalisa data dengan cara mendeskripsikan atau menggambarkan data yang telah terkumpul sebagaimana adanya tanpa bermaksud membuat kesimpulan yang berlaku untuk umum atau generalisasi (Sugiyono 2010). Berikutnya analisis deskriptif juga dilakukan dengan menginterpretasikan nilai rata-rata (mean) setiap jawaban responden berdasarkan variabelnya dan indikatornya masing-masing. Sebagai pedoman dalam mengin terpretasikan jawaban responden, dalam penelitian ini menggunakan SPSS IBM 24.

\section{PEMBAHASAN}

\section{Hasil Uji Hipotesis}

Dalam pembahasan hasil penelitian akan dijelaskan pengaruh langsung, pengaruh tidak langsung dan hasil pengaruh total baik sub struktur 1 mapun sub struktur 2 .

\section{Pengaruh Langsung}

Pengaruh langsung yang akan dijelaskan adalah pengaruh kepemimpinan dan motivasi terhadap kepuasan kerja untuk sub struktur 1, kemudian pengaruh langsung kepemimpinan, motivasi dan kepuasan kerja terhadap kinerja untuk sub struktur 2 .

\section{Uji Substruktur 1}

Hasil analisis jalur pengaruh langsung kepemimpinan dan motivasi terhadap kepuasan kerja tampak pada tabel 4.

\begin{tabular}{l} 
Tabel 3. Koefisien Path Sub Struktur 1 \\
Coefficients \\
Model \\
\hline 1
\end{tabular}

Sumber: Data olahan, 2020.

\section{Pengaruh Kepemimpinan terhadap Kepuasan kerja}

Table 4.23 memperlihatkan bahwa kepemimpinan berpengaruh secara positif dan signifikan terhadap kepuasan kerja yang di tunjukan oleh nilai probabilitas sebesar 0,043 yang lebih kecil dari 0,05 dan nilai $t_{\text {hitung }}$ lebih besar $t_{\text {tabel }}$ yaitu 2,039 > 1,974, dengan koefisien jalur sebesar 0,153 y ang artiny a kepuasan kerja dapat dipengaruhi secara langsung oleh kepemimpinan sebesar 15,3\%, dan arah hubungannya positif, artinya ketika displin di naikan maka kepuasan kerja juga naik, jika kompeten si dinaikan $1 \%$ maka kepuasan kerja juga naik 1 persen. Selanjunya kontribusi kepemimpinan terhadap kepuasan kerja adalah sebesar 0,153 x 0,641 =0,098 atau 9,8\%. Jadi hipotesis 1 yang menyatakan kepemimpinan berpengaruh langsung terhadap kepuasan kerja di Universitas Riau dapat diterima. 


\section{Pengaruh Motivasi terhadap Kepuasan kerja}

Hasil analisis jalur pengaruh langsung motivasi terhadap kepuasan kerja tampak pada tabel 4.23. Motivasi berpengaruh secara positif dan signifikan terhadap kepuasan kerja yang di tunjuk an oleh nilai probabilitas sebesar 0,000 yang lebih kecil dari 0,05 dan nilai $t_{\text {hitung }}$ lebih besar $t_{\text {tabel }}$ yaitu 5,998 > 1,974, dengan koefisien jalur sebesar 0,324 yang artinya motivasi dapat dipengaruhi secara langsung oleh motivasi sebesar 32,4\%, dan arah hubungannya positif, artinya ketika motivasi di naikan maka ke puas an kerja juga naik, jika motivasi dinaikan $1 \%$ maka kepuasan kerja juga naik 1 persen. Selanjunya kontribusi motivasi terhadap kepuasan kerja adalah sebesar 0,324 x 0,607 =0,197 atau 19.7\%. Jadi hipotesis 2 y ang menyatakan motivasi berpengaruh langsung terhadap kepuasan kerja di Universitas Riau dapat diterima.

\section{Pengaruh Komitmen Organisasi terhadap Kepuasan kerja}

Hasil analisis jalur pengaruh langsung komitmen organisasi terhadap kepuasan kerja tampak pada tabel 4.23. komitmen organisasi berpengaruh secara positif dan signifikan terhadap kepuasan kerja yang di tunjukan oleh nilai probabilitas sebesar 0,000 yang lebih kecil dari 0,05 dan nilai $t_{\text {hitung }}$ lebih besar $t_{\text {tabel }}$ yaitu 5,894>1,974, dengan koefisien jalur sebesar 0,458 yang artinya motivasi dapat dipengaruhi secara langsung oleh komitmen organisasi sebesar 45,8\%, dan arah hubungannya positif, artinya ketika komitmen organisasi di naikan maka kepuasan kerja juga naik, jika motivasi dinaikan $1 \%$ maka kepuasan kerja juga naik 1 persen. Selanjunya kontribusi komitmen organisasi terhad ap kepuas an kerja adalah sebesar $0,458 \times 0,731=0,335$ atau $33.5 \%$. Jadi hipotesis 3 yang menyatakan motivasi berpengaruh langsung terhadap kepuasan kerja di Universitas Riau dapat diterima. Selanjutnya hasil analisis jalur pada sub struktur 1 pengaruh langsung kompetensi dan Kepuasan kerja terhadap kepuasan kerja di Universitas Riau dimasukan kedalam persamaan sub stuktur 1 sebagai berikut: 
Kebijakan: Jurnal Ilmu Administrasi

Volume 13, Nomor 1, Januari 2022

E-ISSN: 2656-2820

P-ISSN 1829-5762

$\mathrm{Y}_{1}=p \mathrm{y}_{1} \mathrm{X}_{1} \mathrm{X}_{1}+p \mathrm{y}_{1} \mathrm{X}_{2} \mathrm{X}_{2}+\mathrm{e}_{1}$

$\mathrm{Y}_{1}=0,153 \mathrm{X}_{1}+0,324 \mathrm{X}_{2}+0,458+0,609$

$\mathrm{e}_{1}=\mathrm{V} / 1-\mathrm{R}^{2}$

$\mathrm{e}_{1}=\mathrm{V} / \overline{1-0,629}$

$\mathrm{e}_{1}=\mathrm{V} / 0,371$

$\mathrm{e}_{1}=0,609$

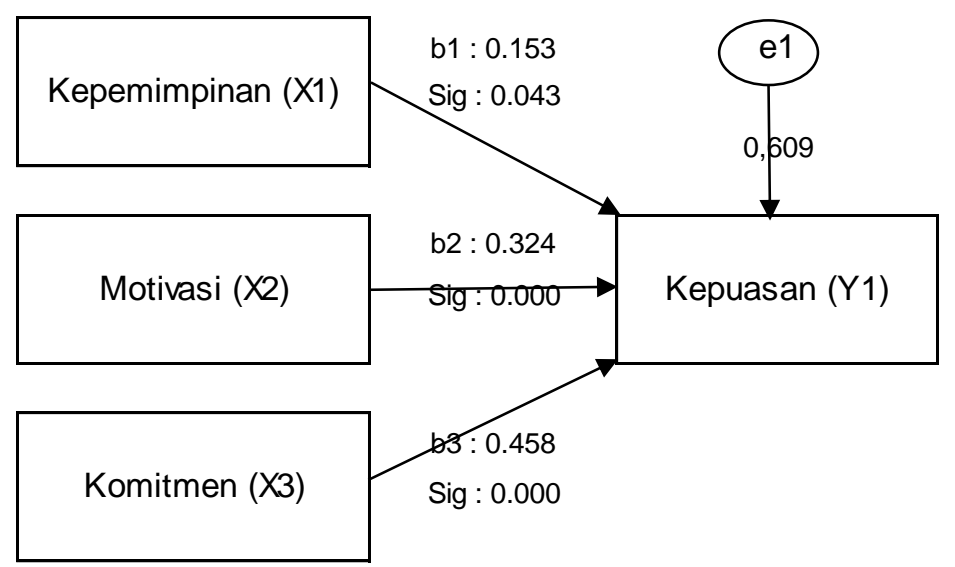

Gambar 1.Path Sub Struktur 1

\section{Uji Substruktur 2}

Hasil analisis jalur pengaruh langsung kepemimpinan dan motivasi dan kepua san kerja terh ad ap kinerja tampak pada tabel 4.

\begin{tabular}{|c|c|c|c|c|c|c|c|c|c|}
\hline \multirow[b]{2}{*}{ Model } & & \multicolumn{2}{|c|}{$\begin{array}{l}\text { Unstandardized } \\
\text { Coefficients }\end{array}$} & \multirow{2}{*}{$\begin{array}{l}\text { Coefficients } \\
\mid \begin{array}{c}\text { Standardized } \\
\text { Coefficients } \\
\text { Beta }\end{array}\end{array}$} & & \multirow{2}{*}{ Sig. } & \multirow{2}{*}{$\begin{array}{l}\text { Corr } \\
\text { Zero-order }\end{array}$} & \multirow[b]{2}{*}{ Partial } & \multirow[b]{2}{*}{ Part } \\
\hline & & B & Std. Error & & $\mathrm{t}$ & & & & \\
\hline 1 & (Constant) & $-0,020$ & 0,109 & & $-0,182$ & 0,856 & & & \\
\hline & Kepemimpin & 0,229 & 0,036 & 0,298 & 6,383 & 0,000 & 0,767 & 0,445 & 0,186 \\
\hline & Motivasi & 0,253 & 0,031 & 0,304 & 8,265 & 0,000 & 0,714 & 0,541 & 0,241 \\
\hline & Komitmen & 0,145 & 0,051 & 0,149 & 2,836 & 0,005 & 0,785 & 0,216 & 0,083 \\
\hline & Kepuasan & 0,395 & 0,054 & 0,354 & 7,386 & 0,000 & 0,839 & 0,498 & 0,215 \\
\hline \multicolumn{10}{|c|}{ a. Dependent Variable: Kinerja } \\
\hline & $R=0.927$ & $R^{2}=0.860$ & Adjusted $R^{2}=$ & $=0.856$ & $=170$ & & & & \\
\hline
\end{tabular}

Sumber: Data olahan, 2020.

\section{Pengaruh kepemimpinan terhadap Kinerja}

Hasil analisis jalur pengaruh langsung kepemimpinan terhadap kinerja tampak pada tabel 4.24. Kepemimpinan berpengaruh secara positif dan signifikan terhadap kinerja yang di tu njukan oleh nilai probabilitas sebesar 0,000 yang lebih kecil dari 0,05 dan nilai $t_{\text {hitung }}$ lebih besar $t_{\text {tabel }}$ yaitu 6,383 > 1,974, dengan koefisien jalur sebesar 0,298 yang artinya kinerja dapat dipengaruhi secara langsung oleh kepemimpinan sebesar 29,8\%, dan arah hubungannya positif, artinya ketika kepemimpinan di naikan maka kinerja juga naik, jika kepemimpinan dinaikan $1 \%$ maka kinerja juga naik 1 persen. Selanjunya 
kontribusi kepemimpinan terhadap kinerja adalah sebesar 0,298 x 0,767 =0,229 atau 22,9\%. Jadi hipotesis 4 yang menyatakan kepemimpinan berpengaruh langsung terhadap kinerja di Universitas Riau dapat diterima.

\section{Pengaruh Motivasi terhadap Kinerja}

Hasil analisis jalur pengaruh langsung motivasi terhadap kinerja tampak pada tabel 4.24. motivasi berpengaruh secara positif dan signifikan terhadap kinerja yang di tunjukan oleh nilai probabilitas sebesar 0,000 yang lebih kecil dari 0,05 dan nilai $t_{\text {hitung }}$ lebih besar $t_{\text {tabel }}$ yaitu 8,265 >1,974, dengan koefisien jalur sebesar 0,304 yang artinya kinerja dapat dipengaruhi secara langsung oleh motivasi sebesar $30.4 \%$, dan arah hubungannya positif, artinya ketika motivasi naik maka kinerja juga naik, jika motivasi naik $1 \%$ maka kinerja juga naik 1 persen. Selanjunya kontribusi motivasi terhadap kinerja adalah sebesar $0,304 \mathrm{x}$ $0,714=0,217$ atau $21,7 \%$. Jadi hipotesis 5 yang menyatakan motivasi berpengaruh langsung terhadap kinerja di Universitas Riau dapat diterima.

\section{Pengaruh Komitmen Organisasi terhadap Kinerja}

Hasil analisis jalur pengaruh langsung komitmen organisasi terhadap kinerja tampak pada tabel 4.24. komitmen organisasi berpengaruh secara positif dan signifikan terhadap kinerja y ang di tunjukan oleh nilai probabilitas sebesar 0,005 yang lebih kecil dari 0,05 dan nilai $t_{\text {hitung }}$ lebih besar $\mathrm{t}_{\text {tabel }}$ yaitu 2,836 $>1,974$, dengan koefisien jalur sebesar 0,149 yang artinya kinerja dapat dipengaruhi secara langsung oleh komitmen organisasi sebesar $14.9 \%$, dan arah hubungannya positif, artinya ketika motiv asi naik maka kinerja juga naik, jika komitmen organisasi naik $1 \%$ maka kinerja juga naik 1 persen. Selanjunya kontribusi komitmen organisasi terhadap kinerja adalah sebesar 0,149 x 0,785 =0,117 atau $11,7 \%$. Jadi hipotesis 6 yang menyatakan komitmen organisasi berpengaruh langsung terhadap kinerja di Universitas Riau dapat diterima.

\section{Pengaruh Kepuasan kerja terhadap Kinerja}

Hasil analisis jalur pengaruh langsung kepuasan kerja terhadap kinerja tampak pada tabel 5. Kepuasan kerja berpengaruh secara positif dan signifikan terhadap kinerja yang di tunjukan oleh nilai probabilitas sebesar 0,007 yang lebih kecil dari 0,05 dan nilai $t_{\text {hitung }}$ lebih besar $t_{\text {tabel }}$ yaitu 7,386 > 1,974, dengan koefisien jalur sebesar 0,354 yang artinya kinerja dapat dipengaruhi secara langsung oleh kepuasan kerja sebesar $35.4 \%$, dan arah hubungannya positif, artinya ketika kepuasan kerja naik maka kinerja juga naik, jika kepuasan kerja naik $1 \%$ maka kinerja juga naik 1 persen. Selanjun ya kontribusi kepuasan kerja terhadap kinerja adalah sebesar 0,354 x 0,839=0,297 atau 29,7\%. Jadi hipote sis 7 yang menyatakan kepuasan kerja berpengaruh langsung terhadap kinerja di Universitas Riau dapat diterima. 
Kebijakan: Jurnal Ilmu Administrasi

Volume 13, Nomor 1, Januari 2022

E-ISSN: 2656-2820

P-ISSN 1829-5762

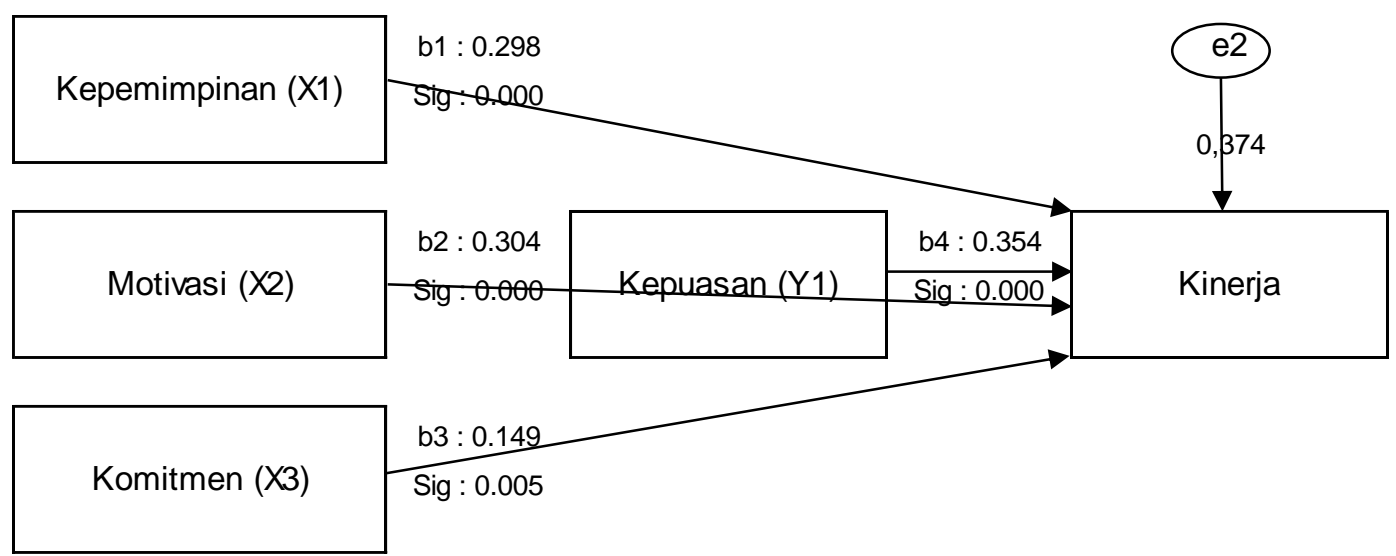

Gambar 2. Path Sub Struktur 2

Pengaruh Tidak Langsung

Pada pengaruh tidak langsung akan dijelaskan pengaruh tidak langsung keemimpinan, motivasi dan kompetensi terhadap kinerja melalui kepuasan kerja.

Pengaruh Kepemimpinan Terhadap Kinerja Melalui Kepuasan kerja

Hasil penelitian menunjukkan bahwa pengaruh kepemimpinan terhadap kinerja melalui kepuasan kerja sebesar nilai koefisien path kepemimpinan dikali dengan nilai koefisien path kepuasan kerja, sehingga diperoleh hasil sebesar $=0,298 \times 0,354=0,298$ atau sebesar 29.8\%. Artinya kepemimpin an dapat mempengaruhi kinerja melalui kepuasan kerja sebesar 29.8\%. Dengan demikian hipotesis 8 yang menyatakan kepemimpinan berpengaruh terhadap kinerja melalui kepuasan kerja di Universitas Riau dapat diterima.

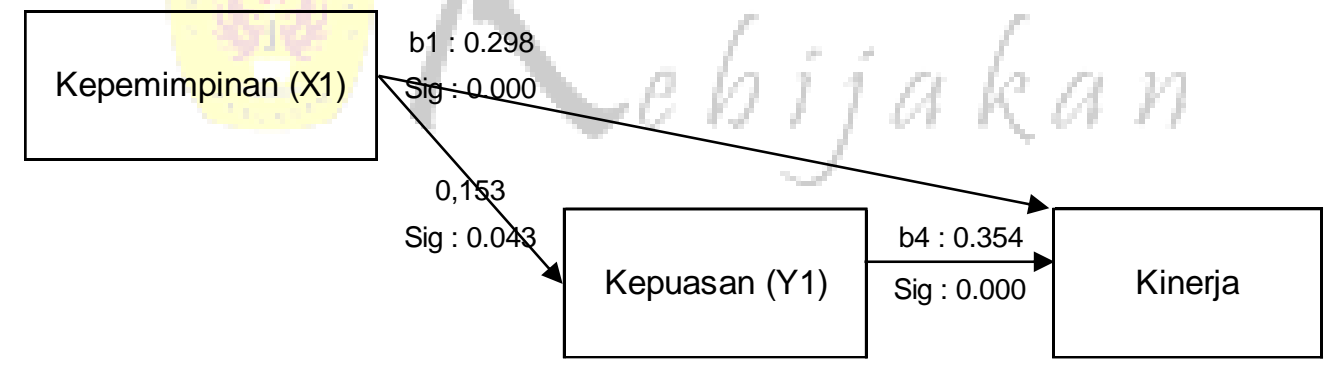

Gambar 3. Pengaruh Kepemimpinan terhadap Kinerja melalui Kepuasan kerja.

\section{Pengaruh Motivasi terhadap Kinerja melalui Kepuasan Kerja}

Hasil penelitian menunjukkan bahwa pengaruh motivasi terhadap kinerja melalui kepu as an kerja sebesar nilai koefisien path motivasi dikali dengan nilai koefisien path kepuasan kerja, sehingga diperoleh hasil sebesar $=0,304 \times 0,354=0,304$ atau sebesar 30,4\%. Artinya motivasi dapat mempengaruhi kin erja melalui kepuasan kerja sebesar 30,4\%. Kemudian struktur path secara keseluruhan tampak pada gamb ar 4.5. Dengan demikian hipotesis 9 yang menyatakan motivasi berpengaruh terhadap kinerja melalui kepuasan kerja di Universitas Riau dapat diterima. 
Kebijakan: Jurnal Ilmu Administrasi

Volume 13, Nomor 1, Januari 2022

E-ISSN: 2656-2820

P-ISSN 1829-5762

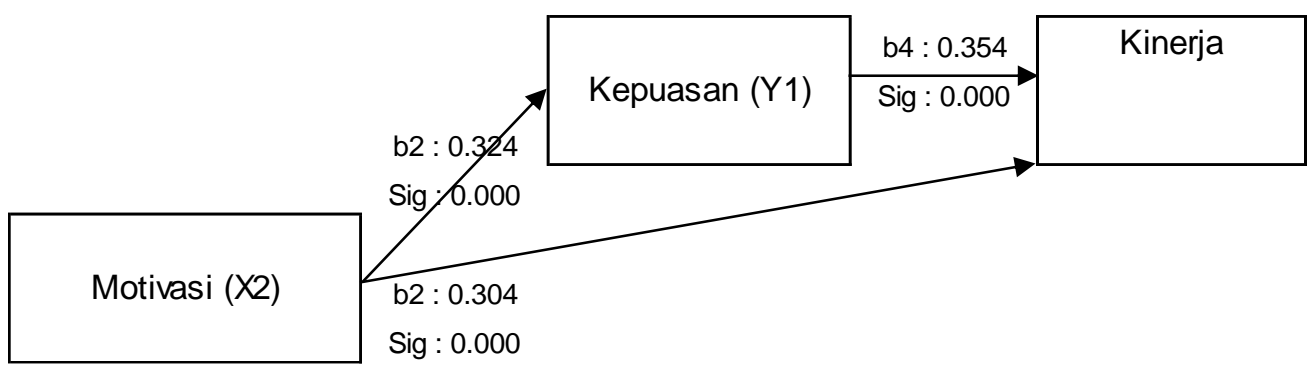

Gambar 4. Pengaruh Motivasi Terhadap Kinerja Melalui Kepuasan Kerja

Selanjutnya secara keluruhan pengaruh langsung, pengaruh tidan langsung dan pengaruh total tampak pada tabel 4.24, dengan adanya penambahan pengaruh tidak langsung (kepemimpin an terhadap kepuasan kerja dan Kepuasan kerja terhadap kepuasan kerja) dengan langsung (kepuasan kerja terhadap kinerja ) maka akan meningkatkan pengaruh yang lebih besar terhadap kinerja di Universitas Riau, y aitu sebesar $0,421+0,117=0,538$ atau sebesar $53,8 \%$ untuk pengaruh motiv asi terhad ap kin erja melalui kepuasan kerja, dan sebesar 0,299 $+0,083=0,362$ atau sebesar $36,2 \%$ untuk motivasi terhadap kinerja melalui kepuasan kerja.

\section{Pengaruh Komitmen Organisasi terhadap Kinerja melalui Kepuasan kerja}

Hasil penelitian menunjukkan bahwa pengaruh komitmen organisasi terhadap kinerja melalui kepuasan kerja sebesar nilai koefisien path komitmen organisasi dikali dengan nilai koefisien path kepuasan kerja, sehingga diperoleh hasil sebesar $=0,149 \times 0,354=0,149$ atau sebes ar $14,9 \%$. Artiny a motivasi dapat mempengaruhi kinerja melalui kepuasan kerja sebesar 14,9\%. Kemu dian struktur path secara keseluruhan tampak pada gambar 4.7. Dengan demikian hipotesis 10 yang menyatakan motivasi berpengaruh terhadap kinerja melalui kepuasan kerja di Universitas Riau dapat diterima.

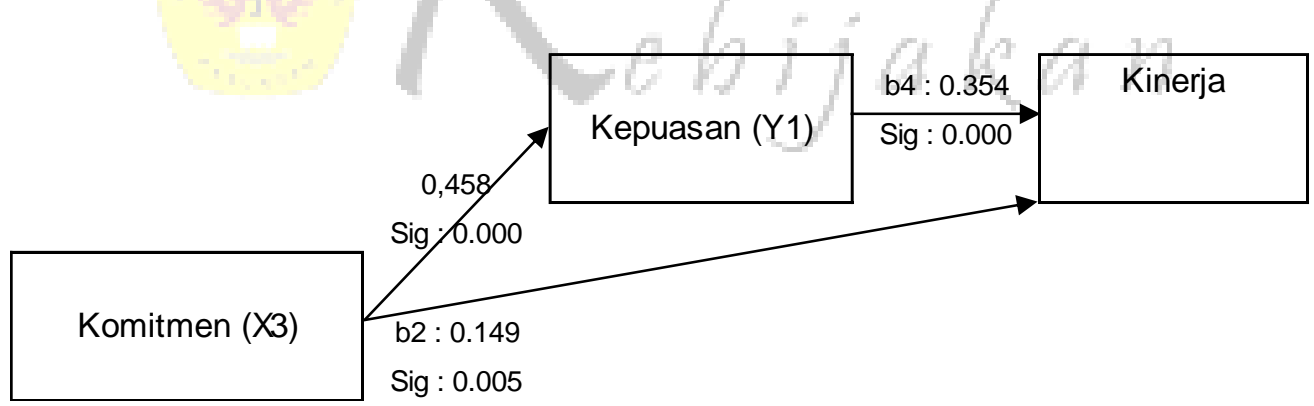

Gambar 5. Pengaruh komitmen terhadap Kinerja melalui Kepuasan kerja

Selanjutnya secara keluruhan pengaruh langsung, pengaruh tidan langsung dan pengaruh total tampak pada tabel 4.24, dengan adanya penambahan pengaruh tidak langsung (kepemimpin an terhadap kepuasan kerja dan Kepuasan kerja terhadap kinerja) dengan langsung (kepuasan kerja terhad ap kinerja ) maka akan meningkatkan pengaruh yang lebih besar terhadap kinerja di Universitas Riau, y aitu sebe sar $0,298+0,105=0,403$ atau sebesar 40,3\% untuk pengaruh motivasi terhadap kinerja melalui kepuasan kerja, sebesar 0,304 +0,091 =0,395 atau sebesar 39,5\% dan untuk komitmen organisasi terhadap kinerja 
Kebijakan: Jurnal Ilmu Administrasi

Volume 13, Nomor 1, Januari 2022

E-ISSN: 2656-2820

P-ISSN 1829-5762

melalui kepuasan kerja sebesar 0,149 +0.045 =0,194 atau sebesar 19.4\%. Kemudian struktur path secara keseluruhan tampak pada tabel 6.

Tabel 5. Pengaruh Langsung, Pengaruh Tidak Langsung Pengaruh Total

Variabel Kepemimpinan dan Motivasi terhadap Kepuasan kerja dan Kinerja

\begin{tabular}{|c|c|c|c|c|c|c|c|}
\hline Hipotesis & Pengujian Antar Variabel & Pengaruh Langsung & $\%$ & Pengaruh tidak Langsung & $\%$ & Total Pengaruh & $\%$ \\
\hline 1 & $\mathrm{X} 1 \rightarrow \mathrm{Y} 1$ & 0,153 & $15.3 \%$ & & & 0,153 & $15.3 \%$ \\
\hline 2 & $\mathrm{X}_{2} \rightarrow \mathrm{Y}_{1}$ & 0,324 & $32.4 \%$ & & & 0,324 & $32.4 \%$ \\
\hline 3 & $X_{3} \rightarrow Y_{1}$ & 0,458 & $45.8 \%$ & & & 0,458 & $45.8 \%$ \\
\hline 4 & $\mathrm{X} 1 \rightarrow \mathrm{Y} 2$ & 0,298 & $29,80 \%$ & & & 0,298 & $29,80 \%$ \\
\hline 5 & $\mathrm{X} 2 \rightarrow \mathrm{Y} 2$ & 0,304 & $30,40 \%$ & & & 0,304 & $30,40 \%$ \\
\hline 6 & $\mathrm{X} 3 \rightarrow \mathrm{Y} 2$ & 0,149 & $14,90 \%$ & & & 0,149 & $14,90 \%$ \\
\hline 7 & $\mathrm{Y}_{1} \rightarrow \mathrm{Y} 2$ & 0,354 & $35,40 \%$ & & & 0,354 & $35,40 \%$ \\
\hline 8 & $\mathrm{X} 1 \rightarrow$ Y2 Melalui Y1 & 0,298 & $29.8 \%$ & 0,105 & $10.5 \%$ & 0,403 & $40.3 \%$ \\
\hline 9 & $\mathrm{X}_{2} \rightarrow$ Y2 Melalui Y1 & 0,304 & $30,40 \%$ & 0,091 & $9.1 \%$ & 0,395 & $39.5 \%$ \\
\hline 10 & $\mathrm{X} 3 \rightarrow$ Y2 Melalui Y1 & 0,149 & $14,90 \%$ & 0,045 & $4.5 \%$ & 0,194 & $19.4 \%$ \\
\hline
\end{tabular}

Sumber: Data olahan, 2020.

\section{SIMPULAN}

Kepemimpinan berpengaruh positif dan signifikan terhadap kepuasan kerja pegawai di Universitas Riau. Artinya semakin baik kepemimpinan maka kepuasan kerja pegawai akan semakin meningkat. Motivasi berpengaruh positif dan signifikan terhadap kepuasan kerja pegawai di Universitas Riau. Artinya semakin baik motivasi yang diberikan kepada pegawai maka kepuasan kerja pegawai akan semakin meningkat. Komitmen organisasi berpengaruh positif dan signifikan terhadap ke puasan kerja pegawai di Universitas Riau. Dengan komitmen pegawai yang baik diharapkan akan mampu meningkatkan kepuasan kerja. Artinya bahwa semakin tinggi komitmen organisasi maka dapat meningkatkan kepuasan kerja pegawai. Kepemimpinan berpengaruh positif dan signifikan terhadap kinerja pegawai di Universitas Riau. Artinya kepemimpinan yang baik mampu meningkatkan kinerja pegawai di Universitas Riau. Motivasi berpengaruh positif dan signifikan terhadap kinerja pegawai di Universitas Riau. Artinya bahwa semakin baik motivasi yang diterima pegawai, maka kinerja pegawai akan semakin meningkat. Komitmen organisasi berpengaruh positif dan signifikan terhadap kinera pegawai di Universitas Riau. Dengan komitmen yang baik diharapkan akan terwujud kinerja y ang baik, berdaya guna dan berhasil guna melalui seperangkat peraturan yang jelas dan tepat. Kepuasan kerja pegawai berpengaruh positif dan signifikan terhadap kinera pegawai di Universitas Riau. Dengan kepuasan kerja yang baik diharapkan akan terwujud kinerja yang baik, berdaya guna dan berhasil gun a melalui seperangkat peraturan yang jelas dan tepat. Kepemimpinan berpengaruh terhadap kinerja melalui kepuasan kerja di Universitas Riau.

Semakin baik kepemimpinan dan diikuti kepuasan kerja yang positif akan meningkatkan Kinerja. Motivasi berpengaruh terhadap kinerja melalui kepuasan kerja di Universitas Riau. Hal ini menunjuk kan motivasi yang baik didukung dengan kepuasan kerja pegawai yang baik juga maka ak an menin gkatkan kinerja. Semakin baik motivasi dan diikuti kepuasan kerja yang positif akan meningkatkan kinerja. Komitmen organisasi berpengaruh terhadap kinerja melalui kepuasan kerja di Universitas Riau. Hal ini menunjukkan komitmen organisasi yang baik didukung dengan kepuasan kerja pegawai yang baik juga 
Kebijakan: Jurnal Ilmu Administrasi

Volume 13, Nomor 1, Januari 2022

E-ISSN: 2656-2820

P-ISSN 1829-5762

maka akan meningkatkan kinerja. Semakin baik komitmen organisasi dan diikuti kepuas an kerja yang positif akan meningkatkan kinerja.

\section{DAFTAR PUSTAKA}

Bangun, Wilson. 2012. Manajemen Sumber Daya Manusia, Erlangga, Bandung.

Darmawan, Didit. 2013. Prinsip-prinsip Perilaku Organisasi. Pena Semesta. Surabaya.

Dharma, Agus, 2009. Manajemen Supervisi : Petunjuk Praktis Bagi ParaSupervisor. Jakarta, Raja Grafindo Persada.

Davis and Newstrom, John W. 2011. Organizational Behavior: Human Behavior at Work. NewyorkAmerica: McGraw-Hill Education.

Edison, Emron, dkk. 2017. Manajemen Sumber Daya Manusia. Alfabeta, Bandung.

Ghozali, Imam. 2011. Aplikasi Analisis Multivariate Dengan Program IBM. SPSS 19 (edisi kelima.) Semarang: Universitas Diponegoro.

Gomes, Cardoso Faustin 2009. Manajemen Sumber Daya Manusia, edisi pertama, cetakan keempat, Andi Off set, Jakarta.

Handoko, T. Hani, 2012. Manajemen Personalia Sumber Daya Manusia, Edisi. Ked ua, Yogy akarta, Penerbit : BPFE.

Hasibuan, Malayu S.P. 2012. Manajemen: Dasar, Pengertian, dan Masalah. Edisi Revisi. Jakarta: Bumi Aksara.

Kasmir. 2016. Manajemen Sumber Daya Manusia. Jakarta: PT. RajaGrafindo Persada.

Kreitner, Robert dan Angelo Kinicki. 2012. Organizational behavioral-Ed. 5. Boston: McGraw-Hill.

Luthans, Fred. 2015. Perilaku Organisasi. Diterjemahkan oleh Vivin Andika Yuwono dkk. Edisi Pertama, Penerbit Andi, Yogyakarta.

Machasin, 2018. Perilaku Organisasi. UR. Press Pekanbaru. Riau.

Machasin, 2017. Analisis Budaya Organisasi, Kualitas Kehidupan Kerja, Dan Komitmen Organisasi Terhadap Implementasi Manajemen Pengetahuan Serta Implikasin ya Bagi Kinerja Kary aw an PDAM Di Provinsi Riau. Disertasi, Pascasarjana Universitas Pasundan.

Mahsun, Mohammad. 2009. Pengukuran Kinerja Sektor Publik. Edisi Ketiga. BPFE, Yogyakarta.

Mangkunegara, Anwar Prabu. 2012. Evaluasi Kinerja SDM. Bandung: Refika Aditama. 2013. Evaluasi Kinerja SDM. Bandung: Refika Aditama.

Martoyo, Susilo. 2010. Manajemen Sumber Daya Manusia, Edisi 5, Cetakan Pertama. Yogyakarta: BPFE.

Pasolong, Harbani. 2010. Kepemimpinan Birokrasi, Bandung: CV Alfabeta.

Ridwan Engkos dan Kuncoro, Achmad. 2015. Cara Menggunakan dan Memaknai Path Analysis, Alf abeta: Bandung.

Rivai, H. V., dan Sagala, E. J., 2011. Manajemen Sumber Daya Manusia untuk Perusahaan dari Teori ke Praktik Edisi 2, Rajawali Pers, Jakarta.

Rivai, Veithzal. 2009. Manajemen Sumber Daya Manusia Untuk Perusahaan. Dari Teori ke Praktik. Jakarta: Raja Grafindo Persada.

Robbins, Stephen P, 2008. Prinsip-Prinsip Perilaku Organisasi. Edisi Kelima: Erlangga, Jakarta. 


\section{Kebijakan: Jurnal Ilmu Administrasi}

Volume 13, Nomor 1, Januari 2022

E-ISSN: 2656-2820

P-ISSN 1829-5762

Robbins, P.Stephen dan Timothy A. Judge. 2012. Perilaku Organisasi. Salemba Empat Jakarta.

Saydam, Gouzali. 2005. Manajemen Sumber daya Manusia: Suatu pendekatan. Mikro. Jakarta: Djambaran.

Silaen, Sofar, dan Widiyono. 2013. Metodologi Penelitian Sosial Untuk Penulis Skripsi dan Tesis. Jakarta; In Media.

Simanjuntak, J. Payaman. 2011. Manajemen dan Evaluasi Kinerja. Jakarta : Lembaga Penerbit Fakultas Ekonomi UI.

Sopiah. 2010. Perilaku Organisasional. Yogyakarta: Andi.

Sugiyono. 2010. Metode Penelitian Pendidikan Pendekan Kuantitatif, kualitatif dan $R \&$ D . Bandung: Alfabeta.

Sutrisno, Edy. 2013. Manajemen Sumber Daya Manusia. Jakarta: Kecana Prenada Media Group.

Sutrisno,. 2015. Budaya Organisasi. Jakarta: Kecana Prenada Media Group.

Tangkilisan, Hessel Nogi S. 2008. Manajemen Publik. Jakarta: PT. Grasindo.

Thoha, Miftah,2010. Perilaku Organisasi Konsep Dasardan Aplikasinya, Jakarta : PT Raja Grafindo Persada.

Uno. Hamzah B. 2012. Teori dan Motivasi dan Pengukurannya (Analisis di bidang pendidikan). Jakarta: PT. Bumi Aksara.Wibowo (2012).

Wibowo, 2012. Manajemen Kinerja. Penerbit Rajawali Press, Jakarta.

Yukl. Gary, 2010, Kepemimpinan dalam Organisasi, Edisi Kelima. Jakarta: PT. Indeks. 